\title{
Emendation of the Genus Blastobacter Zavarzin 1961 and Description of Blastobacter natatorius sp. nov.
}

\author{
L. I. SLY \\ Department of Microbiology, University of Queensland, Brisbane, Queensland, Australia
}

\begin{abstract}
The name Blastobacter natatorius is proposed for a new species of the genus Blastobacter. The type strain is strain UQM 2507, which was isolated from a freshwater swimming pool. $B$. natatorius is a yellow, gram-negative, oxidase-positive organism with rod-shaped or wedge-shaped cells with straight or slightly curved axes. Each: cell has a simple mucilaginous holdfast at its nonreproductive pole by which it attaches to other cells or to solid surfaces to form rosettes. Reproduction occurs by asymmetric division (budding) of the mother cell to produce a spherical or ovoid daughter cell (bud). The free bud cells are motile, and each has a single polar flagellum. This organism is strictly aerobic and chemoorganotrophic. The guanine-plus-cytosine content of the deoxyribonucleic acid of the type strain is $65 \mathrm{~mol} \%$. The description of the genus Blastobacter is emended to include motile organisms and physiological information lacking because a culture of the type species, Blastobacter henricii, has never been isolated.
\end{abstract}

In 1961 Zavarzin (17) propased the genus Blastobacter to include budding rod-shaped bacteria which he observed in a filter paper enrichment of reduced iron-containing water from a northern Russian forest brook. The type species of this genus is Blastobacter henricii, which was named after the American microbiologist A. T. Henrici, who had observed and described similar morphological types in freshwater ponds (3).

Zavarzin was unable to isclate a culture of $B$. henricii, the cells of which were described as being rod shaped or wedge shaped, often slightly curved, and forming rosettes by attaching to each other at the nonreproductive poles of the cells. Single buds were observed on the free reproductive poles of the mother cells. Blastobacter-like bacteria have since been observed in Michigan forest pond and acid bog water habitats (4), and the isolation of Blastobacter strains has recently been reported by a number of workers (5-7, 11a; M. Müller, Ph.D. thesis, University of Kiel, Kiel, Federal Republic of Germany, 1977)

Hirsch (5) reported the isolation of eight pure cultures from a Michigan forest pond, and three additional cultures were isolated from lakes and a pond in Holstein, Federal Republic of Germany (6; Müller, Ph.D. thesis). Loginova and Trotsenko (7) described a new yellow-pigmented species, "Blastobacter viscosus," from activated sludge, which was capable of autotrophic growth in an atmosphere containing $75 \%$ hydrogen, $15 \%$ carbon dioxide, and $10 \%$ oxygen or in a medium with methanol as the sole carbon and energy source.

Elsewhere, Sly and Hargreaves (11a) describe the isolation from a swimming pool of a yellow strain (strain UQM $2507^{\mathrm{T}}$ [ $\mathrm{T}=$ type strain]) of Blastobacter which was significantly different than the yellow strains isolated by Loginova and Trotsenko (7). Attempts to isolate additional Blastobacter strains similar to strain UQM $2507^{\mathrm{T}}$ from aquatic environments have so far been unsuccessful. Strain UQM $2507^{\mathrm{T}}$ was systematically characterized, and the results of this study are reported in this paper. I have been unable to obtain cultures of any of the Blastobacter strains described previously in the literature; consequently, strain UQM $2507^{\mathrm{T}}$ was compared with previously published strain descriptions rather than with the cultures themselves.

\section{MATERIALS AND METHODS}

Bacterial strain. Strain UQM $2507^{\mathrm{T}}$ was isolated from a swimming pool by Sly and Hargreaves (11a) and has been deposited in the culture collection of the Department of Microbiology, University of Queensland, Brisbane, Australia.

Acid production. Acid production from $0.5 \%$ (wt/vol) carbohydrates and sugar alcohols was tested in the fermentation basal medium of Smith et al. (12) modified by the replacement of bromcresol purple indicator with Andrades indicator (1).

Attachment to solid surfaces. The attachment of cells to solid surfaces was studied by immersing sterile cover glasses in peptone-yeast extract-glucose (PYG) medium (14), peptone-yeast extract (PYE) medium (Sly and Hargreaves, in press), or $0.1 \%$ peptone medium inoculated with strain UQM $2507^{\mathrm{T}}$ and incubating these preparations at $25^{\circ} \mathrm{C}$ for periods up to 3 weeks. Cover glasses with adhering bacterial cells were removed and placed in $3 \%$ glutaraldehyde for 1.5 $h(8)$. The cells were then dehydrated in a $25,50,85,95$, and $100 \%$ ethanol series. The cover glasses were then transferred to a $50 \%$ amylacetate-ethanol mixture and then into amylacetate. The preparations were critical point dried, sputter coated with gold in a partial argon atmosphere at 100 milliTorr, and examined in a Philips model SEM505 scanning electron microscope.

Characterization of strain. All of the other methods used for morphological, cultural, and physiological characterization were performed as described elsewhere $(11,11 \mathrm{a})$.

\section{RESULTS AND DISCUSSION}

Description of Blastobacter natatorius sp. nov. The morphology of strain UQM $2507^{\mathrm{T}}$ is shown in Fig. 1, and its general cultural and biochemical characteristics are presented in Table 1.

Strain UQM $2507^{\mathrm{T}}$ was assigned to the genus Blastobacter by Sly and Hargreaves (11a), and further examination of this strain confirmed its inclusion in that genus. Zavarzin (17) described Blastobacter cells as budding, rod shaped or wedge shaped, often slightly curved, and forming rosettes by attaching to each other at the nonreproductive poles of the cells. 

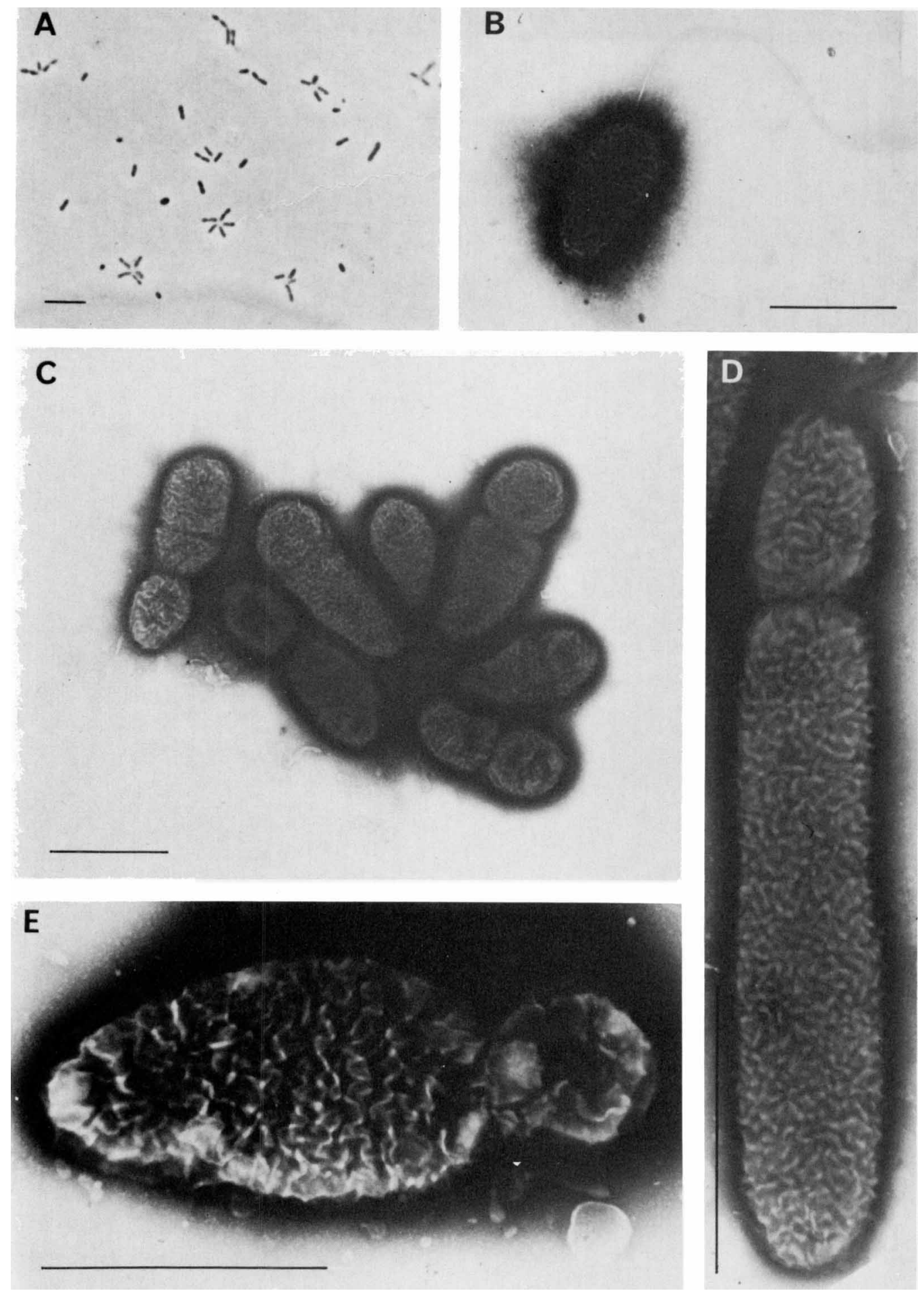

FIG. 1. Morphology of $B$. natatorius UQM $2507^{\mathrm{T}}$. (A) Sample from PYG motility medium showing individual cells and budding cells in rosette formation. Bar $=5 \mu \mathrm{m}$. (B) Electron micrograph of a daughter cell (bud) with a single polar flagellum. Bar $=1 \mu \mathrm{m}$. (C) Electron micrograph of budding cells in rosette formation. Bar $=1 \mu \mathrm{m}$. (D) and (E) Electron micrographs of budding cells. Bar $=1 \mu \mathrm{m}$.

The only valid species of Blastobacter recognized on the Approved Lists of Bacterial Names (10) is the type species, B. henricii. As no pure culture was isolated, the type species and consequently the genus are based on the description of Zavarzin of this organism. A comparison of Fig. 1 with the drawings of Zavarzin (17) clearly shows that strain UQM $2507^{\mathrm{T}}$ conforms with the organism which he described to be included in the genus Blastobacter. However, the lack of information on the color, growth, and physiology of the type species and the lack of a type strain for comparison make it 
TABLE 1. Comparison of the characteristics of $B$. natatorius UQM $2507^{\mathrm{T}}$ with previously published data on other isolates"

\begin{tabular}{|c|c|c|c|c|c|}
\hline Characteristic & $\begin{array}{l}\text { B. natatorius } \\
\text { UQM } 2507^{\text {Ib }}\end{array}$ & $" B$. viscosus" $7 \mathrm{~d}$ & $\begin{array}{c}\text { B. henricii } \\
161 \mathrm{~A}(= \\
\text { IFAM 1003) }\end{array}$ & $\begin{array}{c}\text { "B. } \\
\text { capsulatus" } 216 \\
(=\text { IFAM } \\
1004)^{d}\end{array}$ & $\begin{array}{c}\text { "B. } \\
\text { denitrificans" } \\
222(=\text { IFAM } \\
1005)^{d}\end{array}$ \\
\hline \multicolumn{6}{|l|}{ Cellular morphology } \\
\hline Shape & Rod or wedge & $\begin{array}{l}\text { Rod } \\
\text { (pleomorphic) }\end{array}$ & $\operatorname{Rod}$ & $\begin{array}{l}\text { Rod; old cells } \\
\text { Y-shaped }\end{array}$ & Rod \\
\hline Width $(\mu \mathrm{m})$ & $0.5-0.8$ & $0.5-0.9$ & $0.6-0.8$ & $0.7-0.9$ & $0.6-0.8$ \\
\hline Length $(\mu \mathrm{m})$ & $\begin{array}{l}1-3 \\
\quad(\text { some }>10)\end{array}$ & $1-3.2$ & $1.5-2.3$ & $1.5-2.3$ & $1.5-2.3$ \\
\hline Presence of buds & + & + & + & + & + \\
\hline Position of bud on mother cell & Pole & Pole and side & Pole & Pole & Side \\
\hline Bud shape & $\begin{array}{l}\text { Spherical or } \\
\text { ovoid }\end{array}$ & Ovoid & Rod & Ovoid & Rod \\
\hline Bud width $(\mu \mathrm{m})$ & $0.5-0.8$ & $\mathrm{ND}^{e}$ & ND & ND & ND \\
\hline Bud length $(\mu \mathrm{m})$ & $0.5-1$ & & & & \\
\hline Formation of rosettes & + & - & + & - & - \\
\hline Gram stain & - & - & - & - & - \\
\hline Motility & + & - & + & - & + \\
\hline Flagellation & Single polar & - & ND & - & ND \\
\hline Presence of capsule & - & + & - & + & - \\
\hline Colony pigmentation & Yellow & Yellow & White & White & White \\
\hline Growth temp range $\left({ }^{\circ} \mathrm{C}\right)$ & $11-39$ & $10-34$ & $13.1-43.6$ & $14-41$ & $13.1-46$ \\
\hline Optimum temp range $\left({ }^{\circ} \mathrm{C}\right)$ & $25-30$ & $28-30$ & 36.1 & 27.2 & 41.2 \\
\hline Strict aerobe & + & + & + & + & + \\
\hline Vitamin requirement & - & - & - & - & - \\
\hline $\begin{array}{l}\text { Acid in Hugh-Leifson medium } \\
\text { supplemented with glucose }\end{array}$ & - & ND & $O$ and $F^{\prime}$ & $\mathrm{O}$ and $\mathrm{F}$ & $\mathrm{F}$ \\
\hline \multicolumn{6}{|l|}{ Acid produced from: } \\
\hline Fructose & + & ND & + & + & + \\
\hline Galactose & - & ND & + & + & + \\
\hline Glucose & + & + & + & + & + \\
\hline Glycerol & + & ND & ND & $\mathrm{ND}$ & ND \\
\hline Maltose & + & ND & + & + & + \\
\hline Mannitol & - & ND & + & + & + \\
\hline Mannose & + & ND & ND & ND & ND \\
\hline Melezitose & + & ND & ND & ND & ND \\
\hline Sucrose & + & ND & + & + & - \\
\hline \multicolumn{6}{|l|}{ Growth on: } \\
\hline PYG medium ${ }^{g}$ & + & ND & + & + & + \\
\hline Peptone-yeast extract agar ${ }^{h}$ & + & ND & ND & ND & ND \\
\hline $0.1 \%$ Peptone medium & + & ND & ND & ND & ND \\
\hline Glucose-ammonium agar & + & ND & + & + & + \\
\hline Methanol & - & + & - & - & + \\
\hline \multirow{2}{*}{\multicolumn{6}{|c|}{ Hydrolysis of: }} \\
\hline & & & & & \\
\hline Cellulose & - & - & - & - & - \\
\hline Gelatin & + & - & - & - & - \\
\hline Starch & - & - & - & - & - \\
\hline Tween 80 & + & ND & ND & ND & ND \\
\hline \multicolumn{6}{|l|}{ Production of: } \\
\hline $\mathrm{NO}_{2}$ from $\mathrm{NO}_{3}$ & - & + & - & + & $+\left(\right.$ to $\left.N_{2}\right)$ \\
\hline Indole & - & ND & - & - & - \\
\hline $\mathrm{H}_{2} \mathrm{~S}$ & - & ND & - & - & - \\
\hline \multicolumn{6}{|l|}{ Presence of: } \\
\hline Catalase & + & + & + & + & + \\
\hline Oxidase & + & + & + & + & + \\
\hline Urease & - & - & + & - & + \\
\hline Phosphatase & + & ND & ND & ND & ND \\
\hline Deoxyribonuclease & + & ND & ND & ND & ND \\
\hline $\begin{array}{l}\text { Guanine-plus-cytosine content } \\
(\mathrm{mol} \%)\end{array}$ & 65 & $66.3 \pm 0.9$ & $60.4 \pm 0.4$ & $58.9 \pm 1.3$ & $64.5 \pm 0.8$ \\
\hline $\begin{array}{l}\text { "UQM, Culture Collection, Depart } \\
\text { Universität Kiel, Kiel, Federal Republ } \\
\text { "Data from this study. } \\
\text { "Data from reference } 7 . \\
\text { "Data of Müller (Ph.D. thesis). } \\
\text { " ND, Not determined. } \\
\text { O. Oxidative: F, fermentative. } \\
\text { "See reference 14. } \\
\text { "See reference 11a. }\end{array}$ & $\begin{array}{l}\text { of Microbiology. I } \\
\text { iermany. }\end{array}$ & sity of Queensland. & ne, Australia: I & Institut für Allg & Mikrobiologie, \\
\hline
\end{tabular}


unlikely that any strain could confidently be assigned to the species $B$. henricii, except perhaps a strain from the same habitat.

Consequently, a new species is proposed to include strain UQM $2507^{\mathrm{T}}$, and this species is described below.

Blastobacter natatorius sp. nov. (na. ta. to' ri. us. M.L. masc. adj. natatorius of a swimming place [pool], the source of the water from which the organism was first isolated) cells are gram negative, nonsporing, non-encapsulated, and rod shaped or wedge shaped with straight or slightly curved axes. Cells are usually 0.5 to 0.8 by 1 to $3 \mu \mathrm{m}$ in size. Older cells may become elongated and reach lengths of $10 \mu \mathrm{m}$ or more. Some cells have a swollen or bloated appearance. Cells occur singly or in pairs and readily form rosettes. Each cell has a simple mucilaginous holdfast at its nonreproductive pole, by which it attaches to other cells or solid surfaces to form rosettes. No stalks, prosthecae, or other specialized holdfast structures are present.

Reproduction occurs by asymmetric division (budding) of the mother cell to produce a shorter daughter cell or bud at the free pole of the mother cell. Buds are spherical or ovoid and are usually 0.5 to 0.8 by 0.5 to $1 \mu \mathrm{m}$ in size. The free bud cells are motile, and each has a single polar flagellum.

Colonies grown on peptone-yeast extract agar for 3 days at $28^{\circ} \mathrm{C}$ are yellow and round and have entire edges, diameters of 0.5 to $1.0 \mathrm{~mm}$, and high convex elevations. The colony surface is shiny, and the growth is easily emulsified. After further incubation the colonies have a rubbery consistency and may be removed intact from the agar surface by touching with a wire loop. Colonies on Staley PYG medium after 4 days at $28^{\circ} \mathrm{C}$ are pale pink and $0.5 \mathrm{~mm}$ in diameter.

The organism is strictly aerobic and obligately chemoorganotrophic. Growth occurs on PYG medium, peptoneyeast extract agar, $0.1 \%$ peptone medium, and glucose-ammonium sulfate agar.

No growth occurs in citrate-, phenol-, alkylamine-, or methanol-mineral salts medium, in nitrogen-free medium supplemented with glucose, sucrose, or mannitol as a carbon and energy source, or under autotrophic conditions with ammonium sulfate, sodium nitrite, sodium thiosulfate, ferrous sulfate, or hydrogen.

Catalase, oxidase, phosphatase, and deoxyribonuclease are produced. Gelatin and Tween 80 are hydrolyzed, but cellulose, chitin, alginate, starch, tributyrin, casein, and dextran are not. There is no hemolysis of erythrocytes, and urease, phenylalanine deaminase, arginine dihydrolase, indole, and $\mathrm{H}_{2} \mathrm{~S}$ are not produced. Nitrate is not reduced.

An alkaline reaction occurs in Hugh-Leifson medium. Acid but no gas is produced from fructose, glucose, glycerol, maltose, mannose, melezitose, and sucrose in the medium of Smith et al. (14) modified to contain Andrades indicator.

The guanine-plus-cytosine content of the deoxyribonucleic acid of the type strain is $65 \mathrm{~mol} \%$, as determined by the thermal denaturation method.

The type strain is strain UQM 2507, which was isolated from a freshwater swimming pool.

Attachment to solid surfaces. The mode of attachment of the cells to solid cover glass surfaces was examined in media of various nutritional strengths. The cells attached to the cover glasses by their nonreproductive poles (Fig. 2). In addition, strands were present which were similar in appearance to extracellular material observed in Flavobacterium aquatile (16). These strands represented a glycocalyx (2).

In dilute PYG medium and $0.1 \%$ peptone medium these strands produced minor bridging between cells and between cells and the solid surface or accumulated at the base of the attached cells (Fig. 2A and B). In the richer peptone-yeast extract medium the cells appeared to be draped in a blanket of glycocalyx material (Fig. 2C), and in dilute PYG medium after 3 weeks a web of strands bridged the cells (Fig. 2D).

Comparison with other isolates. Detailed strain data are available for three strains isolated by Müller (Ph.D. thesis) and another strain isolated by Loginova and Trotsenko (7). I have been unable to obtain cultures from any source for inclusion in a comparative study. Therefore, Table 1 shows the previously published properties of these isolates compared with the properties of $B$. natatorius UQM $2507^{\mathrm{T}}$.

There is an overall similarity in cell shape, size, and reproduction by budding which is consistent with the assignment of all of these strains to the genus Blastobacter as described by Zavarzin (17). There are significant differences in the position of the bud on the pole or side of the mother cell, in the motility of bud cells, in the ability to form rosettes, and in colony pigmentation.

Physiologically, all of the isolates were aerobic, catalase and oxidase positive, and able to produce acid from glucose and a number of other sugars.

There is disagreement in the manner of carbohydrate metabolism. Müller (Ph.D. thesis) reported that two of his isolates produced acid both oxidatively and fermentatively in Hugh-Leifson medium and that another strain produced acid only fermentatively. However, fermentative metabolism in the absence of a suitable electron acceptor is inconsistent with the reported aerobic nature of these organisms. In contrast, $B$. natatorius $\mathrm{UQM} 2507^{\mathrm{T}}$ produced an alkaline reaction in Hugh-Leifson medium. Clearly, further examination will be required to elucidate the nature of carbohydrate metabolism in these organisms.

All isolates were unable to degrade cellulose or starch, and $B$. natatorius UQM $2507^{\mathrm{T}}$ was alone in its ability to hydrolyze gelatin. Significant physiological differences among the strains were in their ability to reduce nitrate to nitrite and, in one case, the ability to denitrify to nitrogen gas. Two of the four isolates were capable of utilizing methanol as a source of carbon and energy.

Both Müller (Ph.D. thesis) and Loginova and Trotsenko (7) proposed new names for their isolates. However, these names did not appear on the Approved Lists of Bacterial Names (10) and have not been validly published or revived since 1980 . Consequently, these names have no standing in bacterial nomenclature. Müller identified one of his isolates (strain 161A) as $B$. henricii. Mention has already been made regarding the paucity of information on the type species, $B$. henricii, which was named on the basis of descriptive material as no culture was isolated. It is difficult to see how any strain can be assigned with confidence to the species $B$. henricii. On the basis of cellular morphology and rosette formation, strain UQM $2507^{\mathrm{T}}$ could equally as well have been identified like Müller strain $161 \mathrm{~A}$ as $B$. henricii. Yet these two isolates have different colors, and both are motile and therefore inconsistent with the original description of Zavarzin of $B$. henricii.

In view of the confusion which has arisen from the apparently incorrect designation of strain ATCC 27377 as the type strain of Pasteuria ramosa $(9,13,15)$, a species which was also based on description only, there seem to be good grounds for caution in the assignment of a type strain for B. henricii.

The only previous report of a yellow strain of Blastobacter besides strain UQM $2507^{\mathrm{T}}$ was strain $7 \mathrm{~d}$ of Loginova and Trotsenko (7). However, this organism was significantly 
different than strain UQM $2507^{\mathrm{T}}$. It was nonmotile and showed considerable pleomorphism and lateral budding. Physiologically, unlike strain UQM $2507^{\mathrm{T}}$, it reduced nitrate, grew in a medium with methanol as the sole carbon source, and also was capable of autotrophic growth in an atmosphere containing $75 \%$ hydrogen, $15 \%$ carbon dioxide, and $10 \%$ oxygen.

Emendation of the genus Blastobacter. With the addition of $B$. natatorius to the genus Blastobacter and the strain data of Müller (Ph.D. thesis) and Loginova and Trotsenko (7), the description of this genus needs to be emended as follows.

Cells gram-negative and rod shaped or wedge shaped with straight or slightly curved axes. Cells may be capsulated. Cells are usually 0.5 to 1.0 by 1 to $4.5 \mu \mathrm{m}$ in size. Older cells may become elongated and reach lengths of $10 \mu \mathrm{m}$ or more. Some cells may have a swollen or bloated appearance. Cells occur singly or in pairs and may form rosettes in the center of which there may be a glistening corpuscle. Each rosetteforming cell has a simple mucilaginous holdfast at its nonreproductive pole, by which it attaches to other cells or to solid surfaces. No stalks, prosthecae, or other holdfast structures are present.

Reproduction occurs by asymmetric division (budding) of the mother cell to produce a shorter daughter cell or bud at the free pole of the mother cell. Buds may be spherical, ovoid, or rod shaped and are usually 0.3 to 0.8 by 0.3 to $1 \mu \mathrm{m}$ in size. The free bud cells may be nonmotile or motile with single polar flagella.

Chemoorganotrophic. Good growth occurs on PYG medium or peptone-yeast extract agar. Growth occurs on glucose-ammonium sulfate agar. Methanol may be used by some strains as a source of carbon and energy. One isolate is
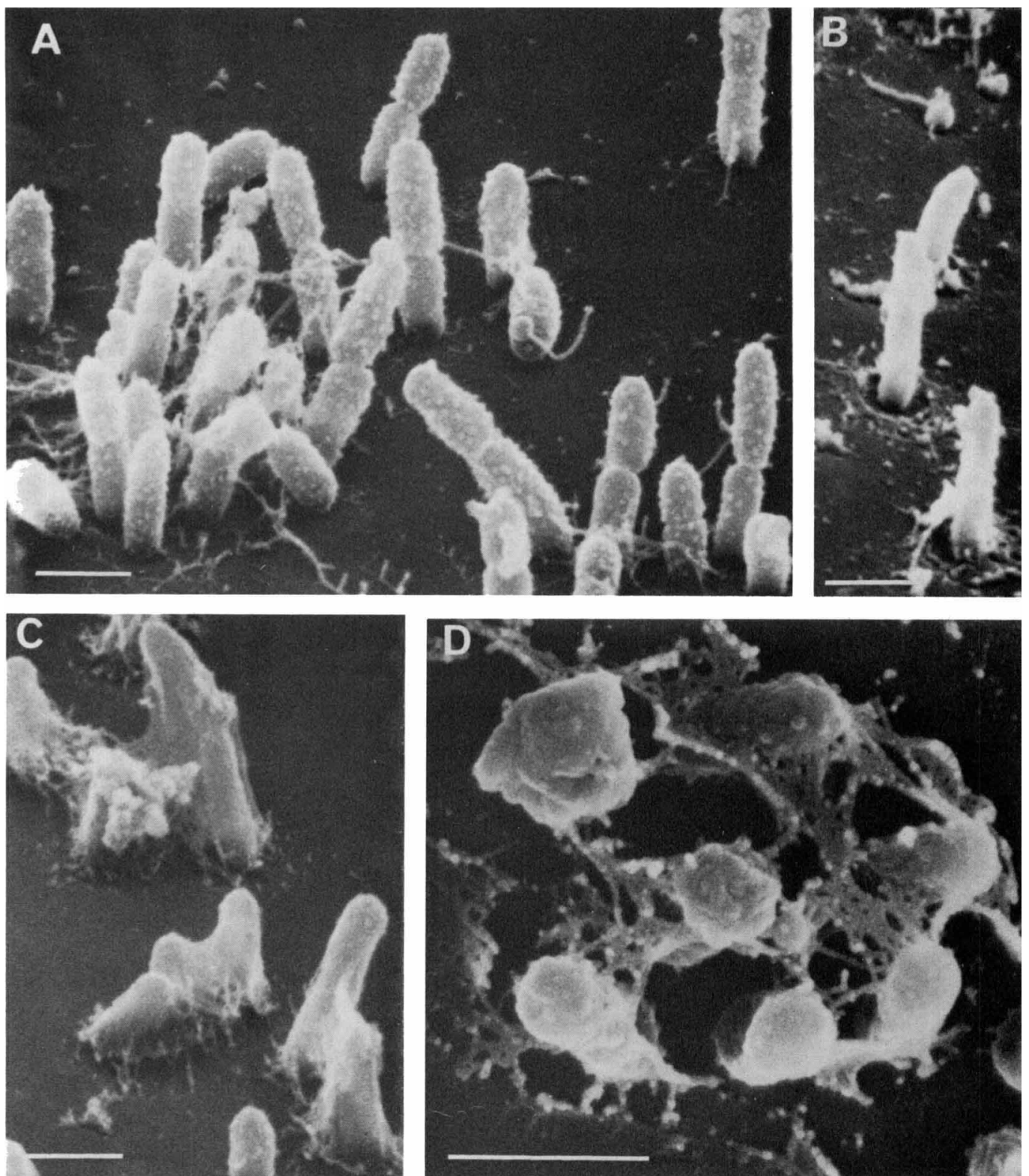

FIG. 2. Scanning electron micrographs showing the attachment of $B$. natatorius UQM $2507^{\mathrm{T}}$ to cover glasses. (A) PYG medium after 3 days. (B) Peptone (0.1\%) medium after 3 days. (C) Peptone-yeast extract medium after 3 days. (D) PYG medium after 3 weeks. Bar $=1 \mu \mathrm{m}$. 
capable of autotrophic growth in an atmosphere containing $75 \% \mathrm{H}_{2}, 10 \% \mathrm{O}_{2}$, and $15 \% \mathrm{CO}_{2}$. No vitamin requirements. Colony pigmentation is white or yellow.

Aerobic. Catalase and oxidase positive. Acid but no gas is produced from glucose. Nitrate may be reduced.

The guanine-plus-cytosine content of the deoxyribonucleic acid ranges from 59 to $66 \mathrm{~mol} \%$.

Found in natural waters.

The type species is Blastobacter henricii Zavarzin 1961.

No type culture has been isolated.

\section{ACKNOWLEDGMENTS}

I thank Christina Kastrissios, Elizabeth Marden, and Gerda Wolff for expert technical assistance and Jane Westcott, Tony McGregor, and John Hardy for electron microscopy.

\section{LITERATURE CITED}

1. Collee, J. G. 1975. Tests for identification of bacteria, p. 170-189. In R. Cruickshank, J. P. Duguid, B. P. Marmion, and R. H. A. Swain (ed.), Medical microbiology, vol. 2. The practice of medical microbiology, 12th ed. Churchill Livingstone. Edinburgh.

2. Costerton, J. W., R. T. Irvin, and K.-J. Cheng. 1981. The bacterial glycocalyx in nature and disease. Annu. Rev. Microbiol. 35:299-324.

3. Henrici, A. T., and D. E. Johnson. 1935. Studies of fresh water bacteria. II. Stalked bacteria, a new order of Schizomycetes. J. Bacteriol. 30:61-93.

4. Hirsch, P. 1974. Budding bacteria. Annu. Rev. Microbiol. 28:391-444.

5. Hirsch, P. 1981. The genus Blastobacter, p. 493-495. In M. P. Starr, H. Stolp, H. G. Trüper, A. Balows, and H. G. Schlegel (ed.), The prokaryotes, vol. 1. Springer-Verlag, Berlin.

6. Hirsch, P., M. Müller, and H. Schlesner. 1977. New aquatic budding and prosthecate bacteria and their taxonomic position. Soc. Appl. Bacteriol. Symp. Ser. 6:107-133.

7. Loginova, N. V., and Y. A. Trotsenko. 1979. Blastobacter viscosus-a new species of autotrophic bacteria utilizing methanol. Mikrobiologiya 48:785-792.

8. Sayre, R. M., J. R. Adams, and W. P. Wergin. 1979. Bacterial parasite of a cladoceran: morphology, development in vivo, and taxonomic relationships with Pasteuria ramosa Metchnikoff 1888. Int. J. Syst. Bacteriol. 29:252-262.

9. Sayre, R. M., R. L. Gherna, and W. P. Wergin. 1983. Morphological and taxonomic reevaluation of Pasteura ramosa Metchnikoff 1888 and "Bacillus penetrans" Mankau 1975. Int. J. Syst. Bacteriol. 33:639-649.

10. Skerman, V. B. D., V. McGowan, and P. H. A. Sneath (ed.). 1980. Approved lists of bacterial names. Int. J. Syst. Bacteriol. 30:225-420.

11. Skerman, V. B. D., L. I. Sly, and M. Williamson. 1983. Conglomeromonas largomobilis gen. nov., sp. nov., a sodium-sensitive, mixed-flagellated organism from freshwaters. Int. J. Syst. Bacteriol. 33:300-308.

11a.Sly, L. I., and M. H. Hargreaves. 1984. Two unusual budding bacteria isolated from a swimming pool. J. Appl. Bacteriol. 56:479-486.

12. Smith, N. R., R. E. Gordon, and F. E. Clark. 1952. Aerobic, spore-forming bacteria. U.S. Dept. Agric. Monogr., vol. 16.

13. Staley, J. T. 1973. Budding bacteria of the Pasteuria-Blastobacter group. Can. J. Microbiol. 19:609-614.

14. Staley, J. T. 1981. The genus Pasteuria, p. 490-492. In M. P. Starr, H. Stolp, H. G. Trüper, A. Balows, and H. G. Schlegel (ed.), The prokaryctes, vol. 1. Springer-Verlag, Berlin

15. Starr, M. P., R. M. Sayre, and J. M. Schmidt. 1983. Assignment of ATCC 27377 to Planctomyces staleyi sp. nov. and conservation of Pasteuria ramosa Metchnikoff 1888 on the basis of type descriptive material. Request for an Opinion. Int. J. Syst. Bacteriol. 33:666-671.

16. Thomson, K. S., T. A. McMeekin, and C. J. Thomas. 1981. Electron microscopic observations of Flavobacterium aquatile NCIB 8694 ( = ATCC 11947) and Flavobacterium meningosepticum NCTC 10016 (= ATCC 13253). Int. J. Syst. Bacteriol. 31:226-231.

17. Zavarzin, G. A. 1961. Budding bacteria. Mikrobiologiya 30: 952-975. 